\title{
Chemical analysis of callus extracts from toxic and non-toxic varieties of Jatropha curcas L.
}

\author{
Gerardo Leyva-Padrón ${ }^{1}$, Pablo Emilio Vanegas-Espinoza ${ }^{1}$, Alma Angélica Del Villar-Martínez ${ }^{1}$, Crescencio \\ Bazaldua ${ }^{\text {Corresp. } 1}$ \\ ${ }^{1}$ Centro de Desarrollo de Productos Bióticos, Instituto Politécnico Nacional, Yautepec, Morelos, México \\ Corresponding Author: Crescencio Bazaldua \\ Email address: cbazaldua@ipn.mx
}

Jatropha curcas L. belongs to Euphorbiaceae family, it synthesizes flavonoid and diterpene compounds that have showed antioxidant, anti-inflammatory, anticancer, antiviral, antimicrobial, antifungal and insecticide activity. Seeds of this plant accumulate phorbol esters, which are tigliane type diterpenes, reported as toxic and, depending on its concentration, toxic and non-toxic varieties has been identified. The aim of this work was to characterize the chemical profile of the extracts from seeds, leaves and callus of both varieties (toxic and non-toxic) of Jatropha curcas, to verify the presence of important compounds in dedifferentiated cells and consider the possibility of using these cultures for the massive production of metabolites. Callus induction was obtained using NAA (1.5

$\left.\mathrm{mg} \cdot \mathrm{L}^{-1}\right)$ and BAP $\left(1.5 \mathrm{mg} \cdot \mathrm{L}^{-1}\right)$ after $21 \mathrm{~d}$ for both varieties. Thin layer chromatography analysis showed differences in compounds accumulation in callus from non-toxic variety throughout the time of culture, diterpenes showed an increase along the time, in contrast with flavonoids which decreased. Based on the results obtained through microQTOF-QII spectrometer it is suggested a higher accumulation of phorbol esters, derived from 12 deoxy-16-hydroxy-phorbol $\left(\mathrm{m} / \mathrm{z} 365[\mathrm{M}+\mathrm{H}]^{+}\right)$, in callus of $38 \mathrm{~d}$ than those of $14 \mathrm{~d}$ culture, from both varieties. Unlike flavonoids accumulation, the MS chromatograms analysis allowed to suggest lower accumulation of flavonoids as the culture time progresses, in callus from both varieties. The presence of 6 glycosylated flavonoids is also suggested in leaf and callus extracts derived from both varieties (toxic and non-toxic), including:

apigenin 6-C- $\alpha$-L-arabinopyranosyl-8-C- $\beta$-D-xylopyranoside $\left(m / z 535[\mathrm{M}+\mathrm{H}]^{+}\right)$, apigenin 4'O-rhamnoside $\left(\mathrm{m} / \mathrm{z} 417[\mathrm{M}+\mathrm{H}]^{+}\right)$, vitexin $\left(\mathrm{m} / \mathrm{z} 433[\mathrm{M}+\mathrm{H}]^{+}\right)$, vitexin 4'-O-glucoside-2"'-Orhamnoside $\left(\mathrm{m} / \mathrm{z} 741[\mathrm{M}+\mathrm{H}]^{+}\right)$, vicenin-2 $\left(\mathrm{m} / \mathrm{z} 595[\mathrm{M}+\mathrm{H}]^{+}\right)$, and vicenin-2,6"-O-glucoside $\left(m / z 757[\mathrm{M}+\mathrm{H}]^{+}\right)$. 


\section{Chemical analysis of callus extracts from toxic and non-toxic} 2 varieties of Jatropha curcas $L$.

3

4 5 6

Gerardo Leyva-Padrón, Pablo Emilio Vanegas-Espinoza, Alma Angélica Del Villar-Martínez, Crescencio Bazaldúa

Departamento de Biotecnología, Centro de Desarrollo de Productos Bióticos-Instituto Politécnico Nacional, Yautepec, Morelos, México.

Corresponding Author:

Crescencio Bazaldúa

Carretera Yautepec-Jojutla, Km. 6, calle Ceprobi No. 8, Col. San Isidro, Yautepec, Morelos. C.P. 62731. México.

Email address: cbazaldua@ipn.mx

\section{Abstract}

Jatropha curcas L. belongs to Euphorbiaceae family, it synthesizes flavonoid and diterpene compounds that have showed antioxidant, anti-inflammatory, anticancer, antiviral, antimicrobial, antifungal and insecticide activity. Seeds of this plant accumulate phorbol esters, which are tigliane type diterpenes, reported as toxic and, depending on its concentration, toxic and non-toxic varieties has been identified. The aim of this work was to characterize the chemical profile of the extracts from seeds, leaves and callus of both varieties (toxic and non-toxic) of Jatropha curcas, to verify the presence of important compounds in dedifferentiated cells and consider the possibility of using these cultures for the massive production of metabolites. Callus induction was obtained using NAA $\left(1.5 \mathrm{mg} . \mathrm{L}^{-1}\right)$ and BAP $\left(1.5 \mathrm{mg} . \mathrm{L}^{-1}\right)$ after $21 \mathrm{~d}$ for both varieties. Thin layer chromatography analysis showed differences in compounds accumulation in callus from non-toxic variety throughout the time of culture, diterpenes showed an increase along the time, in contrast with flavonoids which decreased. Based on the results obtained through microQTOF-QII spectrometer it is suggested a higher accumulation of phorbol esters, derived from 12-deoxy-16-hydroxy-phorbol $(\mathrm{m} / \mathrm{z} 365$ $[\mathrm{M}+\mathrm{H}]^{+}$), in callus of $38 \mathrm{~d}$ than those of $14 \mathrm{~d}$ culture, from both varieties. Unlike flavonoids accumulation, the MS chromatograms analysis allowed to suggest lower accumulation of flavonoids as the culture time progresses, in callus from both varieties. The presence of 6 glycosylated flavonoids is also suggested in leaf and callus extracts derived from both varieties (toxic and non-toxic), including: apigenin $6-C$ - $\alpha$-L-arabinopyranosyl-8- $C-\beta$-D-xylopyranoside $\left(\mathrm{m} / z 535[\mathrm{M}+\mathrm{H}]^{+}\right)$, apigenin 4'-O-rhamnoside $\left(\mathrm{m} / z 417[\mathrm{M}+\mathrm{H}]^{+}\right)$, vitexin $\left(\mathrm{m} / z 433[\mathrm{M}+\mathrm{H}]^{+}\right)$, vitexin 4'-O-glucoside-2"- $O$-rhamnoside $\left(m / z 741[\mathrm{M}+\mathrm{H}]^{+}\right)$, vicenin-2 $\left(m / z 595[\mathrm{M}+\mathrm{H}]^{+}\right)$, and vicenin-2,6"-O-glucoside $\left(\mathrm{m} / \mathrm{z} 757[\mathrm{M}+\mathrm{H}]^{+}\right)$. 


\section{Introduction}

Jatropha curcas L. (Euphorbiaceae) is a multipurpose plant native to Mesoamerica, it is important because of its usefulness as raw material in biofuels production (Salvador-Figueroa et al., 2015), as well as, in veterinary and human traditional medicine (Zhang et al., 2017). Several compounds with different biological activities have been isolated from different species of Jatropha (FerreiraRodriguez et al., 2016; Katagi et al., 2016). The identification of biologically active compounds extracted from different organs of this plant has been reported (Prasad, Izam \& Khan, 2012; Sharma, Dhamija \& Parashar, 2012). Isolated compounds or whole plant extracts have been studied because of their potential pharmacological activity (Cocan et al., 2018). Biological effect of J. curcas includes antibacterial (Rampadarath et al., 2016), cytotoxic (Katagi et al., 2016), antiinflammatory (Salim et al., 2018), and antifungal (Abdelgader, Suleiman \& Ali, 2019; Srinivasan, Palanisamy \& Mulpuri, 2019). Most research on J. curcas have been done with toxic varieties; toxicity is referred to phorbol esters content in seeds.

In Mexico, Brazil and India, it have been identified non-toxic varieties of this species with very low or non-detectable levels of phorbol esters (PEs) in seeds (Laviola et al., 2010; MartínezHerrera, Chel-Guerrero \& Martínez-Ayala, 2004; Kumar, Anand \& Reddy, 2011). PEs are known as Jatropha factors because each one of them has the same nucleus diterpene moiety, namely, 12 deoxy-16-hydroxy-phorbol (DHP) which is coupled to unstables intramolecular diterpenes (named $\mathrm{C}_{1}-\mathrm{C}_{6}$ factors) (Hirota et al., 2017).

Plants are the most successful source of chemical compounds, which potential mode of action makes them an alternative phytomedicinal drug, since several natural products have shown benefits against human diseases (Aye et al., 2019). Several compounds are tissue-specific accumulated, and are usually structurally complex (Armaly et al., 2015). Therefore it is necessary the use of chemical analysis techniques to isolate and identify the extracted plant metabolites (Hernandez \& Sarlah, 2019). There are a few cases where the use of plant cell culture of Jatropha curcas has allowed the production of bioactive compounds (Alvero-Bascos \& Ungson, 2012; Mahalakshmi, Eganathan \& Parida, 2013; Nassar, El-Ahmay \& Al-Azizi, 2013; ZaragozaMartínez et al., 2016), the study of the culture at different stages of toxic and non-toxic varieties, generate the opportunity to design biotechnological models for production of bioactive compounds i.e. terpenoids, alkaloids, flavonoids (Abdelgavir \& Van Staden, 2013; Sabandar et al., 2013) providing opportunities for new drugs discovery.

Secondary metabolites are generally in complex matrices at very low concentrations in plant organs, and lower in dedifferentiated cells. These compounds have a wide range of polarities, therefore it is necessary the use of solvents with different polarity to obtain the extracts (Chemat et al., 2019). The aim of this work was to characterize the chemical profile of the extracts from callus of both varieties (toxic and non-toxic) of Jatropha curcas, through the cell culture, to verify the presence of important compounds in dedifferentiated cells and consider the possibility of using these cultures for the massive production of bioactive compounds. 


\section{Materials \& Methods}

\section{Plant material}

78 Seeds and young leaves of Jatropha curcas were collected. Non-toxic variety samples from Centro de Desarrollo de Productos Bióticos-IPN, Yautepec, Morelos, México (1853'09"N, 9903'38"W). The toxic variety samples were collected from Campo Experimental Zacatepec, Instituto Nacional de Investigaciones Agrícolas y Pecuarias (INIFAP), Zacatepec, Morelos, México (18³9'23"N, $\left.99^{\circ} 11^{\prime} 28^{\prime \prime} \mathrm{W}\right)$.

To induce cell dedifferentiation, two different explants were surface-sterilized according to Vanegas et al., 2002. Leaf blade of approximately $0.25 \mathrm{~cm}^{2}$ and petiole of approximately $3 \mathrm{~mm}$ in length were cultured in MS medium (Murashige \& Skoog, 1962) supplemented with sucrose (30 g. $\left.L^{-1}\right)$, phytagel (3 g.L $\left.{ }^{-1}\right)$ (Sigma-Aldrich $\AA$ ). Since there are no reports of the induction of dedifferentiated cells in the varieties analyzed in this study, the combinations of three concentrations (0.0, 1.5 and $\left.3.0 \mathrm{mg} . \mathrm{L}^{-1}\right)$ of naphthaleneacetic acid (NAA) and 6-benzylaminopurine (BAP) were evaluated according to Verma (2013), $\mathrm{pH}$ was adjusted to 5.7, media were sterilized at $121^{\circ} \mathrm{C}$ for $15 \mathrm{~min}$. Ten explants per Petri dish with 3 repetitions per treatment were incubated at $25 \pm 2{ }^{\circ} \mathrm{C}$, photoperiod of $16 \mathrm{~h}$ light $/ 8 \mathrm{~h}$ darkness for $35 \mathrm{~d}$ (Kumar et al., 2015). Explants dedifferentiation was recorded every seven days using a stereoscopic microscope (Nikon, model SMZ 1500, Japan). In order to observe differences in accumulation of compounds during callus development, completely dedifferentiated cells were cultured under the above described conditions for $38 \mathrm{~d}$, samples were taken on days 0,2 and every $4 \mathrm{~d}$ thereafter.

Fresh washed leaves were indoors dried at $25 \pm 2{ }^{\circ} \mathrm{C}$ during 3 weeks. Seeds without tegument and callus, were oven dried at $50{ }^{\circ} \mathrm{C}$ for $48 \mathrm{~h}$, dried samples were ground with a mortar and sieved through a mesh size $53 \mu \mathrm{m}$.

\section{Ultrasound assisted extraction (UAE)}

UAE was performed with an ultrasound bath Branson (2510R-MTH, CT, USA) with automatic control of time and temperature and ultrasound frequency of $40 \mathrm{kHz}$. $500 \mathrm{mg}$ of grounded biomass dry weight $(\mathrm{dw})$ were placed into a $50 \mathrm{~mL}$ borosilicate glass conical Erlenmeyer flask, then $20 \mathrm{~mL}$ of ethanol $80 \%(\mathrm{v} / \mathrm{v})$ were added, and sonicated at $40 \pm 5{ }^{\circ} \mathrm{C}$ during $30 \mathrm{~min}$ (Bazaldúa et al., 2019; Pandey et al., 2018; Dumitraşcu et al., 2019). During sonication flasks were suspended in the water without contact with the bottom of the ultrasonic bath, subsequently they were vortexed. Supernatant was filtered, concentrated to dryness at $25 \pm 2{ }^{\circ} \mathrm{C}$, and solubilized in $500 \mu \mathrm{L}$ of HPLC grade $\mathrm{MeOH}\left(\right.$ Sigma-Aldrich ${ }^{\circledR}$ ) for chromatographic analysis (Saeed et al., 2006; Liu et al, 2013).

\section{Phorbol esters (PEs) rich defatted extract}

$500 \mathrm{mg}$ of dried sample were packed in a filter paper cartridge and defatted in a Soxhlet equipment with petroleum ether $\left(60-80^{\circ} \mathrm{C}\right)$ (Sigma-Aldrich $\left.{ }^{\circledR}\right)$ for $4 \mathrm{~h}$. Petroleum ether (Fermont $\AA$ ) extract was concentrated using rotary evaporator at $40^{\circ} \mathrm{C}, 90 \mathrm{rpm}$, and $900 \mathrm{mbar}$. The methyl esters in the 
112 resulting oil, were extracted with $\mathrm{MeOH}$, later filtered and concentrated to dryness at $25 \pm 2{ }^{\circ} \mathrm{C}$, 113 then solubilized in $500 \mu \mathrm{L}$ of HPLC grade $\mathrm{MeOH}$ for chromatographic analysis (Demissie \& Lele, 114 2010).

\section{Thin layer chromatography}

116 Extracts were applied on normal phase silica plates (Merck Millipore, $60 \mathrm{~F}_{254}$, Germany). 117 Chloroform-methanol (94:6 and 75:25) were used as mobile phase, reference standards were 118 phorbol-12-myristate 13-acetate (PMA, Sigma-Aldrich ${ }^{\circledR}$ ), quercetin, and vitexin (Sigma119 Aldrich ${ }^{\circledR}$ ), both plates were revealed with anisaldehyde (Kathiravan \& Raman, 2010).

120 To analyze extracts obtained by sonication-ethanol $80 \%$ and Soxhlet-methanol a mobile phase 121 consisting of chloroform-methanol (97:3) was used. The reference standard was PMA, and the 122 plates were cerium sulfate-revealed, then observed at $366 \mathrm{~nm}$, and white light. Retention factor 123 (Rf) and color from the spots were compared with chromatographic terpenes profiles described by 124 Reich \& Schibli (2007).

125

126

127

128

129

130

131

132

133

134

135

136

137

138

139

140

141

142

143

144

145

146

\section{MicrOTOF Q-II analysis}

Electrospray ionization analysis (ESI) was performed using a micrOTOF-Q II mass spectrometer (Bruker Daltonics, Bremen, Germany) according to León-López et al. (2015). Samples were solubilized in $500 \mu \mathrm{L}$ of HPLC grade $\mathrm{MeOH}$ and filtered with a syringe filter (nylon membrane, $0.45 \mu \mathrm{m}$, Agilent Technologies, Santa Clara, CA, USA). The molecular ions related to the extracts were analyzed in positive ion mode $\left(\mathrm{ESI}^{+}\right) .20 \mu \mathrm{L}$ of sample were directly injected into the evaporation chamber, capillary potential was $-4.5 \mathrm{kV}$, gas temperature of $200{ }^{\circ} \mathrm{C}$, drying gas flow of $4 \mathrm{~L} \mathrm{~min}^{-1}$ and nebulizer gas pressure of 0.4 Bar. Detection was performed at $50-3000 \mathrm{~m} / \mathrm{z}$. The predictive structures of the MS/MS partitioning profile were established utilizing the Competitive Fragmentation Modeling for Metabolite Identification (CFM-ID. Version 3.0, 2019) platform from Wishart-lab (http://cfmid3.wishartlab.com), which is referred to in the PubChem-NCBI site. Relative abundance was calculated according to Scigelova et al. (2011).

\section{Results}

\section{Establishment of callus culture}

Dedifferentiation cell was not observed in leaf blade explants. Petiole explants showed tissue dedifferentiation since seventh day of culture and complete process was evident at the day 21 (Fig. 1). Friable and light green callus was obtained on MS media added with both combinations: NAA (1.5 mg. $\left.\mathrm{L}^{-1}\right)$, BAP (1.5 mg. $\left.\mathrm{L}^{-1}\right)$, and NAA (3.0 mg. $\left.\mathrm{L}^{-1}\right)$ and BAP (3.0 mg. $\left.\mathrm{L}^{-1}\right)$.

\section{Thin layer chromatography (TLC) analysis}

TLC showed differences in compounds accumulation during time culture $(2,6,10,14,18,22,26$, 30, 34 and 38 d). Regard diterpenes, spots with $\mathrm{Rf}$ of 0.71 and 0.27 showed higher intensity along this period (Fig. 2A), unlike flavonoids in which spots with $\mathrm{Rf}$ of 0.77 and 0.58 , decreased 
147 throughout the same culture period (Fig. 2B). These results suggest that the accumulation of 148 diterpenes and flavonoids was inversely related during callus development. To obtain diterpenes 149 the Soxhlet-methanol extraction was more efficient than sonication-ethanol $80 \%$. TLC analysis of

150

151

152

153

154

155

156

157

158

159

160

161

162

163

164

165

166

167

168

169

170

171

172

173

174

175

176

177

178

179

180

181

182

183

184

extracts obtained by both methods evidenced differences in the size and intensity of spots in regard to: extraction method, variety (toxic and non-toxic), and plant material (seeds, leaves and callus) (Fig. S1).

\section{MicrOTOF Q-II and competitive fragmentation modeling for metabolite identification platform (CFM-ID)}

\section{Phorbol esters (PEs) analysis}

Fragmentation profile analysis from seeds extract from both varieties showed several highs signals one of them with $\mathrm{m} / \mathrm{z}$ of $365[\mathrm{M}+\mathrm{H}]^{+}$corresponding to 12-deoxy-16-hydroxy-phorbol (DHP), which is the fundamental structural core of the PEs. The MS/MS analysis of this molecular ion showed fragments with $\mathrm{m} / \mathrm{z}$ of $295,276,234,203,185$ and $127[\mathrm{M}+\mathrm{H}]^{+}$which is similar to the fragmentation profile of DHP presented in CFM-ID platform (Fig. 3), this suggests the identification of that molecular structure in all of the extracts obtained from seeds and callus of both toxic and non-toxic varieties. Based on signals intensities from $14 \mathrm{~d}$ and $38 \mathrm{~d}$ callus extracts from both varieties, it is suggested that the accumulation of DHP is time-dependent. Since, the corresponding signal was higher in callus of $38 \mathrm{~d}$ than in those of $14 \mathrm{~d}$ (Fig. 4). Furthermore, two signals with $m / z$ of 547 and $591[\mathrm{M}+\mathrm{H}]^{+}$were observed, so it is proposed that they are related with the fragmentation profile of the signal with $\mathrm{m} / z$ of $711[\mathrm{M}+\mathrm{H}]^{+}$corresponding to any of the Jatropha factors $\left(\mathrm{C}_{1}\right.$ or DHPB to $\mathrm{C}_{6}$ ) which nucleus structure is DHP (Wink et al., 2000; Haas, Sterk \& Mittelbach, 2002) (Fig. S2). Table 1 shows the relative abundance of DHP molecular ion $\left(\mathrm{m} / z 365[\mathrm{M}+\mathrm{H}]^{+}\right)$on $14 \mathrm{~d}$ and $38 \mathrm{~d}$ callus extracts from both varieties, evidencing the increment of these compounds through the callus development.

\section{Flavonoids analysis}

On the other hand, the main group of compounds in Jatropha leaf extracts are flavonoids, among them the apigenin, nevertheless, it is important to refer that the natural condition of flavonoids in the plants is in glycosylated form. On this regard, another of the highest signals observed at the chromatograms was the $m / z$ of $381[\mathrm{M}+\mathrm{H}]^{+}$ion, the MS-MS experiment of this signal and the proposed structures obtained by CFM-ID platform allowed to relate that molecular ion $(\mathrm{m} / \mathrm{z} 381$ $\left.[\mathrm{M}+\mathrm{H}]^{+}\right)$to the fragmentation profiles of apigenin $6-C-\alpha$-L-arabinopyranosyl-8- $C-\beta$-Dxylopyranoside, and of apigenin 4'-O-rhamnoside (Fig. 5). The fragmentation signals and their corresponding predictive structure were also related for vitexin $\left(\mathrm{m} / \mathrm{z} 433[\mathrm{M}+\mathrm{H}]^{+}\right)$, vitexin $4^{\prime}-O-$ glucoside-2 "-O-rhamnoside $\left(\mathrm{m} / z 741[\mathrm{M}+\mathrm{H}]^{+}\right)$, vicenin-2 $\left(\mathrm{m} / z 595[\mathrm{M}+\mathrm{H}]^{+}\right)$, and vicenin-2,6"- $O$ glucoside $\mathrm{m} / \mathrm{z} 757[\mathrm{M}+\mathrm{H}]^{+}$(Fig. S3). Table 1 shows the relative abundance of six tentatively identified compounds by relating their molecular ions on $14 \mathrm{~d}$ and $38 \mathrm{~d}$ callus extracts from both varieties. Inversely to observed on DHP related signal $\left(\mathrm{m} / z 365[\mathrm{M}+\mathrm{H}]^{+}\right)$, the intensity of the molecular ion related with glycosylated apigenin $\left(\mathrm{m} / z 381[\mathrm{M}+\mathrm{H}]^{+}\right)$diminished (Fig. 6).

Peer) reviewing PDF | (2020:02:45707:1:0:NEW 1 Sep 2020) 


\section{Discussion}

186 The highest callus induction (95.5\%) was observed in petiole explants on MS medium added with 187 NAA (3.0 mg.L $\left.\mathrm{L}^{-1}\right)$ and BAP (3.0 mg. $\left.\mathrm{L}^{-1}\right)$, the second best result (87.7\%) was obtained with NAA 188 (1.5 mg. $\left.\mathrm{L}^{-1}\right)$ and BAP (1.5 mg.L $\left.\mathrm{L}^{-1}\right)$, in contrast to reported by Nassar et al. (2013), who observed 189 dedifferentiation with NAA and BAP at $0.5 \mathrm{mg} . \mathrm{L}^{-1}$ of each one plant growth regulator. Explants 190 dedifferentiation reported in this work was similar to reported by Kumar et al. (2015). The follow

191

192

193

194

195

196

197

198

199

200

201

202

203

204

205

206

207

208

209

210

211

212

213

214

215

216

217

218

219

220

221

222

223

up of the explants dedifferentiation process, every $7 \mathrm{~d}$ showed callus formation on explants starting on the seventh day. Dedifferentiation began at the cutting sites as expected (Sujatha, Makkar \& Becker 2005; Nogueira et al., 2011; Ovando-Medina et al., 2016). The callus obtained was light green and friable, similar to reported by Hernández et al. (2015). It has been reported that high auxins concentrations could affect production and accumulation of secondary metabolites (Kim et al., 2007), hence, according to our results, it is suggested the use of the lowest effective concentration, $1.5 \mathrm{mg} . \mathrm{L}^{-1}$ for both growth regulators. Muñoz-Valverde et al. (2003) concluded that BAP is determinant to induce callus formation in foliar explants of J. curcas. Likewise, Suárez \& Salgado (2008) reported that the presence of NAA induce callus formation in Stevia rebaudiana, and this effect could be increased when adding BAP. On the other hand, Solange et al. (2002) determined that the use of NAA and BAP in equal proportion induces callus formation from leaf explants of Tridax procumbens. Coutiño-Cortés et al. (2013) reported the callus induction in $J$. curcas leaf explants at $10 \mathrm{~d}$ of culture, and total explant-cell dedifferentiation at $20 \mathrm{~d}$ using 2, 4$\mathrm{D}, \mathrm{BAP}$ and KIN, while in this work, petioles dedifferentiation started at $7 \mathrm{~d}$ and total explant-cell dedifferentiation was achieved at $21 \mathrm{~d}$. These results support that synergy between NAA and BAP is essential to achieve a high dedifferentiation degree. Stable callus culture conditions for the two varieties of Jatropha curcas were established.

The PEs are responsible for the toxicity in the plant (Devappa, Makkar \& Becker, 2011; Sabandar et al., 2013; Zhang et al., 2017). There are varieties of Jatropha curcas denominated as toxic and non-toxic (Makkar et al., 1997). The non-toxic varieties have PEs concentration lower than 0.86 $\mathrm{mg} / \mathrm{g}$ of seed on dry basis (He et al., 2011). Martínez-Herrera et al. (2006) detected high levels of PEs in seed oil from the municipality of Coatzacoalcos, Veracruz, México, but did not detect PEs in seeds from the municipality of Yautepec, Morelos, México. This corroborates the differences between the seeds of the two varieties used in this study.

Regard, to TLC profile analysis, it has been reported that methanolic extraction from seed-oil facilitates separation and availability of methyl ester type compounds, mainly phorbol esters (PEs) (Demissie \& Lele, 2010; Devappa, Bingham \& Khanal, 2013). The detection by TLC of PEs in seed methanolic extracts from toxic and non-toxic J. curcas varieties was reported (Devappa, Makkar \& Becker (2012), they reported higher spots intensity from toxic variety than from nontoxic, when plates were observed at $366 \mathrm{~nm}$ UV light, this result is similar to that observed in this work (Fig. S1). Makkar \& Becker (2009) detected higher PEs accumulation in seeds than in leaves extracts. Similar results were obtained in this work, even with different method of extraction. Nevertheless, these results are different of that obtained by Martínez-Herrera, Chel-Guerrero \&

Peer) reviewing PDF | (2020:02:45707:1:0:NEW 1 Sep 2020) 
224 Martínez-Ayala, 2004, because they reported 96\% of PEs extraction through hydroalcoholic 225 extraction, quantified by HPLC; while, in this work the intensity of the spots was higher on 226 Soxhlet-methanol extracts than hydroalcoholic extraction (Fig. S1). Using TLC, differences 227 between dedifferentiated cell extracts of both varieties of Jatropha curcas were evidenced.

228 On the other hand, Hirota et al. (2017) reported the identification of DHP as the fundamental 229 structural core which is derived from 12-deoxy-16-hydroxy-phorbol-4'-[12',14'-butadienyl]-6'230 [16',18',20'-nonatrienyl]- bicycle [3.1.0] hexane-(13-O)-2'- [carboxylate]- (16-O)-3'- [8'-butenoic$2311^{\prime}$ '] ate (DHPB or Jatropha factor $\mathrm{C}_{1}$ ), identified as DHPB-Na adduct $\mathrm{m} / z 733[\mathrm{M}+\mathrm{Na}]^{+}$. 232 Furthermore, DHPB $m / z 711[\mathrm{M}+\mathrm{H}]^{+}$and DHP $m / z$ of $365[\mathrm{M}+\mathrm{H}]^{+}$were also reported in $J$. curcas 233 seeds (Wink et al., 2000). Even more so, Haas, Sterk \& Mittelbach, (2002) reported the 234 identification of diterpenes named Jatropha factors $\mathrm{C}_{2}$ to $\mathrm{C}_{6}$ through ESI-MS $m / z 711[\mathrm{M}+\mathrm{H}]^{+}$and 235 of DHP $\left(\mathrm{m} / \mathrm{z}\right.$ of $\left.365[\mathrm{M}+\mathrm{H}]^{+}\right)$. Furthermore, Nishshanka et al. (2016) identified six phorbol esters 236 in J. curcas seeds by LC-MS, which have the same core (DHP), at the so named Jatropha factors $237\left(\mathrm{C}_{1}\right.$ to $\left.\mathrm{C}_{6}\right)$.

238

239

240

241

242

243

244

245

246

247

248

249

250

251

252

253

254

255

256

257

258

259

260

261
Regard to PEs identification by ESI-MS analysis, Verardo et al. (2019) identified six phorbol esters in $J$. curcas seeds with $m / z$ of $711[\mathrm{M}+\mathrm{H}]^{+}$, which have the same fundamental structural core (DHP) $m / z$ of $365[\mathrm{M}+\mathrm{H}]^{+}$which is coupled to diterpenes of 24 carbon structures named Jatropha factors from $\mathrm{C}_{1}(\mathrm{DHPB})$ to $\mathrm{C}_{6}$. The relative intensity of the molecular ion $m / z 365[\mathrm{M}+\mathrm{H}]^{+}$was higher in seeds extracts from toxic variety, than in seed extracts from non-toxic variety (Data not shown). While in callus, the relative intensity is higher in toxic and non-toxic varieties callus of $38 \mathrm{~d}$ of culture (Fig. 4B, and 4D), than in toxic and non-toxic varieties callus of $14 \mathrm{~d}$ of culture (Fig. 4A, and 4C). These results could suggest the presence of PEs coupled to DHP in the samples analyzed and that their accumulation is differential in regard to the variety-derived cell culture and throughout the time of culture. These results suggest that their accumulation of DHP is time dependent. This ESI-MS analysis allowed to corroborate the results obtained by TLC (Fig. 2A). Nevertheless, the relative intensity of the signals observed in extracts from callus were lower than that obtained from seeds extracts as reported by Demissie \& Lele (2010). By ESI-MS, differences in the relative intensity of the signal corresponding to DHP were observed between the callus extracts of both varieties, being higher in the toxic variety in addition to that in calluses at $38 \mathrm{~d}$ of culture, it was higher than in the $14 \mathrm{~d}$.

By other hand, phenolic compounds are ubiquitously produced by plants (Kumar \& Goel, 2019), the main role of phenols in plants is to protect them from biotic or abiotic stress (Pereira, 2016). These properties include antimicrobial, insecticidal, antiparasitic, antiviral, anti-ulcerogeBynic, cytotoxic, antioxidant, anti-hepatotoxic, anti-hypertensive and anti-inflammatory activities (Oskoueian et al., 2011; Papalia, Barreca \& Panuccio, 2017). Flavonoids are recognized as polyphenols. Several of them have been identified in Jatropha genus, such as apigenin glycosides, vitexin, and isovitexin which have been considered as chemiotaxonomic compounds from the genus (Abdelgadir \&Van Staden, 2013; Huang et al., 2014).

Peer] reviewing PDF | (2020:02:45707:1:0:NEW 1 Sep 2020) 
262 The tentative identification of glycosylates-flavonoids through microQTOF-QII has been already 263 reported (Pezzini et al., 2019). In this regard Xie et al. (2003) reported the apigenin 6-C- $\alpha$-L264 arabinopyranosyl-8-C- $\beta$-D-xylopyranoside $m / z 535[\mathrm{M}+\mathrm{H}]^{+}$. Likewise, this result may be related 265 to that obtained by Abd-Alla et al. (2009) who identified apigenin and its aglycone as majoritarian 266 flavonoids in J. curcas leaves, as well as, that obtained by Reena, Nand \& Sharma, (2008) who 267 reported to apigenin as major flavonoid in the same species. Those reports differ from that 268 published by Papalia, Barreca \& Panuccio, (2017) who identified to vitexin and vicenin-2 as the 269 majoritarian flavonoids.

270 The results obtained by microQTOF-QII of the molecular ion $m / z 381[\mathrm{M}+\mathrm{H}]^{+}$through the 271 MS/MS experiment, and the predictive structures obtained through the CFM-ID platform allowed 272 to suggest the relation of the structures from the molecular ion $m / z 381[\mathrm{M}+\mathrm{H}]^{+}$with the 273 fragmentation profile from apigenin 6-C- $\alpha$-L-arabinopyranosyl-8- $C$ - $\beta$-D-xylopyranoside $m / z 535$ $274[\mathrm{M}+\mathrm{H}]^{+}$, which was identified through ESI-MS in Viola yedoensis (Xie et al., 2003) and apigenin 275 4'-O-rhamnoside $m / z 417[\mathrm{M}+\mathrm{H}]^{+}$, which was identified in Olea europaea (Pieroni et al., 1996).

276 Based on the molecular ion, MS-MS fragmentation profile and the predictive structures obtained 277 by CFM-ID platform, it is suggested the tentative identification of vitexin $\mathrm{m} / z$ of $433[\mathrm{M}+\mathrm{H}]^{+}$, 278 vicenin- $2 \mathrm{~m} / z$ of $595[\mathrm{M}+\mathrm{H}]^{+}$, and vitexin 4'-O-glucoside-2 "- $O$-rhamnoside $m / z$ of $741[\mathrm{M}+\mathrm{H}]^{+}$in 279 leaves and callus from both varieties. These results are similar to obtained by Huang et al. (2014) 280 who identified vitexin $\mathrm{m} / \mathrm{z}$ of $433[\mathrm{M}+\mathrm{H}]^{+}$in $J$. curcas leaves. This flavonoid was also identified 281 by ESI-MS in Parkinsonea aculeata $m / z$ of 431 [M-H] - (Hassan, Abdelaziz \& Al Yousef., 2019). 282 In this work it is also suggested the tentative identification of vicenin-2,6"-O-glucoside $\mathrm{m} / z 757$ $283[\mathrm{M}+\mathrm{H}]^{+}$which has not been reported to Jatropha curcas, but to Stellaria holostea (Bouillant et al., 284 1984) (Fig. S2). By the MS-MS fragmentation profile, the identification of six glycosylated 285 flavonoids is suggested, it was observed that relative intensities signals related to flavonoid related 286 molecular ion $m / z 381[\mathrm{M}+\mathrm{H}]^{+}$in callus of $14 \mathrm{~d}$ was higher than callus of $38 \mathrm{~d}$, differences that were not observed between calluses of the different varieties.

\section{8}

289

290

291

292

293

294

295

296

\section{7}

\section{Conclusions}

Stable dedifferentiated cells culture from petiole explants of Jathopha curcas, were stablished from toxic and non-toxic varieties on MS medium added with NAA and BAP. Thin layer chromatography and mass spectrometry, suggest an inverse relationship between phorbol esters and flavonoids accumulation in callus throughout the time of culture. The tentative identification of diterpene type compounds such as 12-deoxy16-hydroxy-phorbol and Jatropha factors by ESI-MS in seed and callus (14 and $38 \mathrm{~d}$ ), as well as, the presence of six flavonoids glycosides in leaf and callus, in extracts from both toxic and non-toxic varieties of $J$. curcas, is suggested. Both of them, groups of compounds reported with bioactive activity with pharmaceutic/agroindistrial potential.

\section{Acknowledgements}


298

299

300

301

302

303

304

305

306

307

308

309

310

311

312

313

314

315

316

317

318

319

320

321

322

323

324

325

326

327

328

329

330

331

332

333

334

335

336

This work was supported by Instituto Politécnico Nacional (IPN/COFAA/SIP-20195486). Gerardo Leyva Padrón acknowledges his study grant from CONACYT. We recognize Centro de Nanociencias y Micro y Nanotecnologías (CNMN-IPN) for the experimental service with the micrOTOF-Q II spectrometer. IPN). We thank Dra. Silvia Evangelista Lozano from Centro de Desarrollo de Productos Bióticos (CEPROBI-IPN), for providing the non-toxic variety plant material, thanks also to Dr. Edwin Javier Barrios Gómez from Instituto Nacional de Investigaciones Forestales, Agrícolas y Pecuarias (INIFAP-Mor, Mexico), for facilitating the toxic variety plant material.

\section{References}

Abd-Alla HI, Moharram FA, Gaara AH, El-Safty MM. 2009. Phytoconstituents of Jatropha curcas L. leaves and their immunomodulatory activity on humoral and cell-mediated immune response in chicks. Zeitschrift für Naturforschung C 64(7-8), 495-501 DOI: 10.1515/znc2009-7-805.

Abdelgader MGM, Suleiman EA, Ali SI. 2019. Study of Jatropha curcas as antifungal agent. International Journal of Current Medical and Pharmaceutical Research 5(5), 4202-4210 DOI: $10.24327 / 23956429 . i j c m p r 201905657$.

Abdelgadir HA, Van Staden J. 2013. Ethnobotany, ethnopharmacology and toxicity of Jatropha curcas L. (Euphorbiaceae): a review. South African Journal of Botany 88, 204-218 DOI: 10.1016/j.sajb.2013.07.021.

Alvero-Bascos EM, Ungson LB. 2012. Ultraviolet-B (UV-B) radiation as an elicitor of flavonoids production in callus cultures of jatropha (Jatropha curcas L.). Philippine Agricultural Scientist 95(4), 335-343.

Armaly AM, DePorre YC, Groso EJ, Riehl PS, Schindler CS. 2015. Discovery of novel synthetic methodologies and reagents during natural product synthesis in the post-palytoxin era. Chemical Reviews 115(17), 9232-9276 DOI: 10.1021/acs.chemrev.5b00034.

Aye MM, Aung HT, Sein MM, Armijos C. 2019. A review on the phytochemistry, medicinal properties and pharmacological activities of 15 selected Myanmar medicinal plants. Molecules 24(2), 293 DOI: 10.3390/molecules24020293.

Chemat F, Abert-Vian M, Fabiano-Tixier AS, Strube J, Uhlenbrock L, Gunjevic V, Cravotto G. 2019. Green extraction of natural products. Origins, current status, and future challenges. TrAC Trends in Analytical Chemistry 118, 248-263 DOI: 10.1016/j.trac.2019.05.037.

Cocan I, Alexa E, Danciu C, Radulov I, Galuscan A, Obistioiu D, Dehelean CA. 2018. Phytochemical screening and biological activity of Lamiaceae family plant extracts. Experimental and Therapeutic Medicine 15(2), 1863-1870 DOI: 10.3892/etm.2017.5640.

Coutiño-Cortés AG, Ovando-Medina I, Adriano-Anaya ML, Salvador-Figueroa M, RuizGonzález S. 2013. Organogénesis de Jatropha curcas a partir de plantas adultas: Estudio de fitohormonas y factores fisicoquímicos. Quehacer Científico en Chiapas 8(2), 2013. 
337

338

339

340

341

342

343

344

345

346

347

348

349

350

351

352

353

354

355

356

357

358

359

360

361

362

363

364

365

366

367

368

369

370

371

372

373

374

375

376

Demissie AG, Lele SS. 2010. Bioassay-assisted identification of phorbol ester from Jatropha curcas (Linn.) tissue culture. International Journal of Pharma and Bio Sciences 1(3), 75.

Devappa RK, Bingham JP, Khanal SK. 2013. High performance liquid chromatography method for rapid quantification of phorbol esters in Jatropha curcas seed. Industrial Crops and Products, 49, 211-219 DOI: 10.1016/j.indcrop.2013.04.044.

Devappa RK, Makkar HP, Becker K. 2011. Jatropha diterpenes: a review. Journal of the American Oil Chemists' Society 88(3), 301-322 DOI: 10.1007/s11746-010-1720-9.

Devappa RK, Makkar HP, Becker K. 2012. Localisation of antinutrients and qualitative identification of toxic components in Jatropha curcas seed. Journal of the Science of Food and Agriculture 92(7), 1519-1525 DOI: 10.1002/jsfa.4736.

Dumitraşcu L, Enachi E, Stänciuc N, Aprodu J. 2019. Optimization of ultrasound assisted extraction of phenolic compounds from cornelian cherry fruits using response surface methodology. CyTA-Journal of Food 17(1), 814-823 DOI: 10.1080/19476337.2019.1659418.

Ferreira-Rodrigues SC, Rodrigues CM, Dos Santos MG, Gautuz JAA, Silva MG, Cogo JC, Oshima-Franco Y. 2016. Anti-inflammatory and antibothropic properties of Jatropha elliptica, a plant from brazilian cerrado biome. Advanced Pharmaceutical Bulletin 6(4), 573 DOI: 10.15171/apb.2016.071.

Haas W, Sterk H, Mittelbach M. 2002. Novel 12-Deoxy-16-hydroxyphorbol diesters isolated from the seed oil of Jatropha curcas. Journal of Natural Products 65(10), 1434-1440 DOI: $10.1021 / \mathrm{np} 020060 \mathrm{~d}$.

Hassan WH, Abdelaziz S, Al Yousef HM. 2019. Chemical composition and biological activities of the aqueous araction of Parkinsonea aculeata L. growing in Saudi Arabia. Arabian Journal of Chemistry 12(3), 377-387 DOI: 10.1016/j.arabjc.2018.08.003.

He W, King AJ, Khan MA, Cuevas JA, Ramiaramanana D, Graham IA. 2011. Analysis of seed phorbol-ester and curcin content together with genetic diversity in multiple provenances of Jatropha curcas L. from Madagascar and Mexico. Plant Physiology and Biochemistry 49(10), 1183-1190 DOI: 10.1016/j.plaphy.2011.07.006.

Hernández LR, Mendiola MAR, Castro CA, Gutiérrez-Miceli FA. 2015. Effect of plant growth regulators on fatty acids composition in Jatropha curcas L. callus culture. Journal of Oleo Science 64(3), 325-330 DOI: 10.5650/jos.ess14206.

Hernandez LW, Sarlah D. 2019. Empowering synthesis of complex natural products. ChemistryA European Journal 25(58), 13248-13270 DOI: 10.1002/chem.201901808.

Hirota F, Maitree S, Anchalee R, Keisuke L, Pornngarm L. Sonthaya U, Masami S. 2017. Phorbol esters in seed oil of Jatropha curcas L. (saboodam in Thai) and their association with cancer prevention: from the initial investigation to the present topics. Journal of Cancer Research and Clinical Oncology 143:1359-1369 DOI: 10.1007/s00432-017-2341-6.

Huang Q, Guo Y, Fu R, Peng T, Zhang Y, Chen F. 2014. Antioxidant activity of flavonoids from leaves of Jatropha curcas. Science Asia 40, 193-197 DOI: 10.2306/scienceasia15131874.2014.40.193.

Peer) reviewing PDF | (2020:02:45707:1:0:NEW 1 Sep 2020) 
390

391

392

393

394

395

396

397

398

399

400

401

402

403

404

405

406

407

408

409

410

411

412

413

414

415

416

Katagi A, Sui L, Kamitori K, Suzuki T, Katayama T, Hossain A, Tokuda M. 2016. Inhibitory effect of isoamericanol A from Jatropha curcas seeds on the growth of MCF-7 human breast cancer cell line by G2/M cell cycle arrest. Heliyon 2(1), e00055 DOI: 10.1016/j.heliyon.2015.e00055.

Kathiravan G, Raman VS. 2010. In vitro taxol production, by Pestalotiopsis breviseta-a first report. Fitoterapia 81(6), 557-564 DOI: 10.1016/j.fitote.2010.01.021.

Kim YS, Yeung EC, Hahn EJ, Paek KY. 2007. Combined effects of phytohormone, indole-3butyric acid, and methyl jasmonate on root growth and ginsenoside production in adventitious root cultures of Panax ginseng CA Meyer. Biotechnology Letters 29(11), 1789-1792 DOI: 10.1007/s10529-007-9442-2.

Kumar N, Anand KV, Reddy MP. 2011. In vitro regeneration from petiole explants of non-toxic Jatropha curcas. Industrial Crops and Products 33(1), 146-151 DOI: 10.1016/j.indcrop.2010.09.013.

Kumar N, Goel N. 2019. Phenolic acids: Natural versatile molecules with promising therapeutic applications. Biotechnology Reports e00370 DOI: 10.1016/j.btre.2019.e00370.

Kumar S, Kumar V, Sharma MK, Kumar N, Kumar A, Tomar KPS, Jaiswal N. 2015. Effects of different plant growth regulators on in vitro callus induction in physic nut (Jatropha curcas L.). Journal of Applied and Natural Science 7(1), 30-37 DOI: 10.31018/jans.v7i1.559.

Laviola BG, Rocha RB, Kobayashi AK, Rosado TB, Bhering LL. 2010. Genetic improvement of Jatropha for biodiesel production. Ceiba 51(1), 1-10 DOI: 10.5377/ceiba.v51i1.640.

León-López L, Márquez-Mota CC, Velázquez-Villegas LA, Gálvez-Mariscal A, Arrieta-Báez D, Dávila-Ortíz G, Torres N. 2015. Jatropha curcas protein concentrate stimulates insulin signaling, lipogenesis, protein synthesis and the PKC $\alpha$ pathway in rat liver. Plant Foods for Human Nutrition 70(3), 351-356 DOI: 10.1007/s11130-015-0502-9.

Mahalakshmi R, Eganathan P \& Parida AK. 2013. Salicylic acid elicitation on production of secondary metabolites by cell cultures of Jatropha curcas L. International Journal of Pharmacy and Pharmaceutical Science 5(4), 655-659.

Makkar HP, Becker K. 2009. Jatropha curcas, a promising crop for the generation of biodiesel and value-added coproducts. European Journal of Lipid Science and Technology 111(8), 773-787 DOI: 10.1002/ejlt.200800244.

Makkar HPS, Becker K, Sporer F, Wink M. 1997. Studies on nutritive potential and toxic constituents of different provenances of Jatropha curcas. Journal of Agricultural and Food Chemistry 45(8), 3152-3157 DOI: 10.1021/jf970036j.

Martínez-Herrera J, Chel-Guerrero L, Martínez-Ayala AL. 2004. The nutritional potential of Mexican piñon (Jatropha curcas). Toxic and antinutritional factors. Publication-European Association for Animal Production 110, 185-188 DOI: 10.3920/978-90-8686-524-6.

Martínez-Herrera J, Siddhuraju P, Francis G, Dávila-Ortíz G, Becker K. 2006. Chemical composition, toxic/antimetabolic constituents, and effects of different treatments on their levels, in four provenances of Jatropha curcas L. from Mexico. Food Chemistry 96(1), 8089 DOI: 10.1016/j.foodchem.2005.01.059.

Peer) reviewing PDF | (2020:02:45707:1:0:NEW 1 Sep 2020) 
417 Muñoz-Valverde J, Valerín-Berrocal K, Alvarenga-Venutolo S, Alán-Fonseca E. 2003. Cultivo in 418 vitro de tempate (Jatropha curcas). Revista Tecnología en Marcha 16(4), 53-59.

419

420

421

422

423

424

425

426

427

428

429

430

431

432

433

434

435

436

437

438

439

440

441

442

443

444

445

446

447

448

449

450

451

452

453

454

455

456

Murashige T, Skoog F. 1962. A revised medium for rapid growth and bio assays with tobacco tissue cultures. Physiologia Plantarum 15(3), 473-497 DOI: $10.1111 / \mathrm{j} .1399$ 3054.1962.tb08052.x.

Nassar SA, El-Ahmady SH, Nassar AH, Al-Azizi MM. 2013. Studying the possible biotransformation of the cytotoxic diterpenoid paclitaxel using Jatropha curcas cell suspension culture. European Journal of Medicinal Plants 3(2), 241-253.

Nishshanka U, Jayasuriya H, Chattopadhaya C, Kijak PJ, Chu PS, Reimschuessel R, De Alwis HG. 2016. Screening for toxic phorbol esters in jerky pet treat products using LCMS. Journal of Chromatography B 1020, 90-95 DOI: 10.1016/j.jchromb.2016.03.02.

Nogueira AR, Soares AA, Ibrahim AB, Campos FA. 2011. Analysis of organogenic competence of cotyledons of Jatropha curcas and their in vitro histological behavior. African Journal of Biotechnology 10(54), 11249-11258 DOI: 10.5897/AJB11.978.

Oskoueian E, Abdullah N, Ahmad S, Saad WZ, Omar AR, Ho YW. 2011. Bioactive compounds and biological activities of Jatropha curcas L. kernel meal extract. International Journal of Molecular Sciences 12(9), 5955-5970 DOI: 10.3390/ijms12095955.

Ovando-Medina I, Pérez-Díaz LP, Ruiz-González S, Salvador-Figueroa M, Urbina-Reyes ME, Adriano-Anaya L. 2016. Production of cytotoxic compounds in dedifferentiated cells of Jatropha curcas L. (Euphorbiaceae). PeerJ 4: e2616 DOI: 10.7717/peerj.2616.

Pandey A, Belwal T, Sekar TC, Bhatt ID, Rawa RS. 2018. Optimization of ultrasonic-assisted (UAE) of phenolics and antioxidant compounds from rhizomes of Rheum moorcroftianum using response surface methodology (RSM). Industrial Crops and Products 119(1), 28225 DOI: $10.1016 /$ j.indcrop.2018.04.019.

Papalia T, Barreca D, Panuccio MR. 2017. Assessment of antioxidant and cytoprotective potential of Jatropha (Jatropha curcas) grown in Southern Italy. International Journal of Molecular Sciences 18(3), 660 DOI: 10.3390/ijms18030660.

Pereira A. 2016. Plant abiotic stress challenges from the changing environment. Frontiers in Plant Science 7, 1123 DOI: 10.3389/fpls.2016.01123.

Pezzini V, Agostini F, Smiderle F, Touguinha L, Salvador M, Moura S. 2019. Grape juice byproducts extracted by ultrasound and microwave-assisted with different solvents: a rich chemical composition. Food Science and Biotechnology28(3), 691-699 DOI: 10.1007/s10068-018-0531-x.

Pieroni A, Heimler D, Pieters L, Van Poel B, Vlietinck AJ. 1996. In vitro anti-complementary activity of flavonoids from oliva (Olea europaea L.) leaves. Pharmazie 51(10), 765-767.

Prasad DR, Izam A, Khan MMR. 2012. Jatropha curcas: plant of medical benefits. Journal of Medicinal Plants Research 6(14), 2691-2699 DOI: 10.5897/JMPR10.977.

Rampadarath S, Puchooa D, Jeewon R. 2016. Jatropha curcas L: Phytochemical, antimicrobial and larvicidal properties. Asian Pacific Journal of Tropical Biomedicine 6(10), 858-865 DOI: 10.1016/j.apjtb.2016.01.019.

Peer] reviewing PDF | (2020:02:45707:1:0:NEW 1 Sep 2020) 
457 Reena T, Nand KS, Sharma PB. 2008. Therapeutic biology of Jatropha curcas: A mini review.

458

459

460

461

462

463

464

465

466

467

468

469

470

471

472

473

474

475

476

477

478

479

480

481

482

483

484

485

486

487

488

489

490

491

492

493

494

495

496 Current Pharmaceutical Biotechnology 9(4) DOI: 10.2174/138920108785161505.

Reich E, Schibli A. 2007. High-Performance Thin-Layer Chromatography for the Analysis of Medicinal Plants. Thieme Medical Publishers Inc. New York, NY.

Sabandar CW, Ahmat N, Jaafar FM, Sahidin I. 2013. Medicinal property, phytochemistry and pharmacology of several Jatropha species (Euphorbiaceae): a review. Phytochemistry 85, 7-29 DOI: 10.1016/j.phytochem.2012.10.009.

Saeed MK, Deng Y, Perveen Z, Ahmad W, Dai R, Yu Y. 2006. Optimal recovery of apigenin from Torreya grandis by extraction, fractionation and structure elucidation. In: Proceedings of the 2006 WSEAS International Conference on Cellular and Molecular Biology, Biophysics and Bioengineering (pp. 32-38).

Salim MN, Masyitha D, Harris A, Balqis U, Iskandar CD, Hambal M. 2018. Anti-inflammatory activity of Jatropha curcas Linn. latex in cream formulation on CD68 expression in mice skin wound. Veterinary World 11(2), 99 DOI: 10.14202/vetworld.2018.99-103.

Salvador-Figueroa M, Magaña-Ramos J, Vázquez-Ovando JA, Adriano-Anaya ML, OvandoMedina I. 2015. Genetic diversity and structure of Jatropha curcas L. in its centre of origin. Plant Genetic Resources 13(1), 9-17 DOI: 10.1017/S1479262114000550

Scigelova M, Hornshaw M, Giannakopoulos A, Makarov A. 2011. Fourier transform mass spectrometry. Molecular \& Cellular Proteomics 10(7), M111.009431. DOI: 10.1074/mcp.M111.009431.

Sharma S, Dhamija HK, Parashar B. 2012. Jatropha curcas: A Review. Asian Journal of Research in Pharmaceutical Science 2(3), 107-111.

Solange E, Pereira J, Ramalho A, Arbex N, Cardoso M, Alves O. 2002. Indução de calos em ervade-touro (Tridax procumbens L.) utilizando diferentes reguladores de crescimento e tipos de explantes. Ciencia e Agrotecnologia 26(2):301-308.

Srinivasan N, Palanisamy K, Mulpuri S. 2019. Jatropha: Phytochemistry, pharmacology, and toxicology. In: Jatropha, Challenges for a New Energy Crop 415-435 DOI: 10.1007/978981-13-3104-6_20.

Suárez IE, Salgado JA. 2008. Propagación in vitro de Stevia rebaudiana Bert. (AsteraceaeEupatorieae) a través de organogénesis. Temas Agrarios 13(1).

Sujatha M, Makkar HPS, Becker K. 2005. Shoot bud proliferation from axillary nodes and leaf sections of non-toxic Jatropha curcas L. Plant Growth Regulation 47(1), 83-90 DOI: 10.1007/s10725-005-0859-0.

Vanegas-Espinoza P, Cruz-Hernández A, Valverde ME, Paredes-López O. 2002. Plant regeneration via organogenesis in marigold. Plant Cell, Tissue and Organ Culture 69(3), 279-283 DOI: 10.1023/A:1015610011374.

Verardo G, Baldini M, Ferfuia C, Gorassini A. 2019. Rapid and selective screening for toxic phorbol esters in Jatropha curcas seed oil using high-performance liquid chromatographyelectrospray ionization-tandem mass spectrometry. Journal of Chromatography A 1597, 63-75 DOI: 10.1016/j.chroma.2019.03.015. 
497

498

499

500

501

502

503

504

505

506

507

508

509

510

511

512

513

514

515

516

517

10
Verma KC. 2013. Micropropagation study of Jatropha curcas for enhancing shoot induction frequency. International Journal of Agriculture, Environment and Biotechnology 6(2), 217.

Wink M, Grimm C, Koschmieder C, Sporer F, Bergeot O. 2000. Sequestration of phorbol esters by the aposematically coloured bug Pachycoris klugii (Heteroptera: Scutelleridae) feeding on Jatropha curcas (Euphorbiaceae). Chemoecology 10(4), 179-184 DOI: 10.1007/PL00001820.

Xie C, Veitch NC, Houghton PJ, Simmonds MSJ. 2003. Flavone C-glycosides from Viola yedoensis Makino. Chemical and Pharmaceutical Bulletin 51(10), 1204-1207 DOI: 10.1248/cpb.51.1204.

Zaragoza-Martínez F, Lucho-Constantino GG, Ponce-Noyola T, Esparza-García F, Poggi-Varaldo H, Cerda-García-Rojas CM, Trejo-Tapia G \& Ramos-Valdivia AC. 2016. Jasmonic acid stimulates the oxidative response and triterpene production in Jatropha curcas cell suspension cultures through mevalonate as biosynthetic precursor. Plant Cell, Tissues and Organ Culture (PCTOC) 127(1), 47-56 DOI: 10.1007/s11240-016-1028-z.

Zhang Y, Yang Q, Li Ch, Ding M, Lv X, Tao Ch, Yu H, Chen F, Ying Xu Y. 2017. Curcin C, a novel type I ribosome-inactivating protein from the post-germinating cotyledons of Jatropha curcas. Amino Acids 49, 1619-1631 DOI 10.1007/s00726-017-2456-8. 
518 Figures description

519 Figure 1. Cell dedifferentiation of petiole explants from both toxic and non-toxic varieties of

520 Jatropha curcas. (A-D) Explants from non-toxic variety throughout dedifferentiation experiment $521(0,7,14$, and $21 \mathrm{~d}$, respectively), (E-H) Explants from toxic variety throughout dedifferentiation 522 experiment $(0,7,14$, and $21 \mathrm{~d}$, respectively). Both induced on MS culture medium added with 523 NAA (1.5 mg. $\left.\mathrm{L}^{-1}\right)$ and BAP (1.5 mg.L $\left.{ }^{-1}\right)$.

524 Figure 2. Identification of both diterpenes-type (A), and flavonoids-type (B) compounds in 525 seeds, leaves, and callus of Jatropha curcas, through thin layer chromatography. Lanes from 5262 to 38 correspond to extracts of callus of non-toxic variety throughout $38 \mathrm{~d}$ of culture, NTS= Non527 toxic variety-seeds, $\mathrm{PMA}=$ Phorbol-12-myristate-13-acetate (Sigma) reference standard ( $\mathrm{Rf} 0.42)$, 528 IV= Isovitexin (Sigma) reference standard (Rf 0.42), and Q= Quercetin (Sigma) reference standard 529 (Rf 0.37). A) The spots intensity increased throughout to culture time ( $\operatorname{Rfs} 0.71$, and 0.27 ), mobile 530 phase chloroform-methanol (94:6). B) The spots intensity decreased throughout to culture time 531 (Rfs 0.77, and 0.58), mobile phase chloroform-methanol (75:25). Plates were revealed with 532 anisaldehyde.

533 Figure 3. Spectrophotometrical analysis of phorbol esters in extracts of Jatropha curcas 534 seeds. MS/MS fragmentation profile of the molecular ion $m / z 365[\mathrm{M}+\mathrm{H}]^{+}$related to 12-deoxy535 16-hydroxy-phorbol, which is the structural core from Jatropha curcas-phorbol esters (referred as 536 Jatropha factors). Predictive structures obtained through CFM-ID platform from each ionized 537 fragment.

538

539

540

541

542

543

544

545

546

547

548

549

550

551

552

553

Figure 4. Mass spectra from callus extracts of $J$. curcas showing the relative intensity of the molecular ion $m / z 365[\mathrm{M}+\mathrm{H}]^{+}$related to the structural core of the Jatropha-phorbol esters. Callus extracts from toxic variety: (A) $14 \mathrm{~d}$ of culture; (B) $38 \mathrm{~d}$ of culture; non-toxic variety: (C) $14 \mathrm{~d}$ of culture, (D) $38 \mathrm{~d}$ of culture. The relative intensity from molecular ion $\mathrm{m} / \mathrm{z} 365[\mathrm{M}+\mathrm{H}]^{+}$ increased throughout culture time.

Figure 5. Fragmentation profile (MS/MS) of the molecular ion $m / z 381[\mathrm{M}+\mathrm{H}]^{+}$, observed in leaves extracts, and related to fragmentation of two glycosylated apigenin (apigenin (apigenin 6-C- $\alpha$-L-arabinopyranosyl-8- $C$ - $\beta$-D-xylopyranoside $m / z 535[\mathrm{M}+\mathrm{H}]^{+}$, apigenin $\mathbf{4}^{\prime}-$ $\boldsymbol{O}$-rhamnoside $\left.\boldsymbol{m} / \boldsymbol{z} 417[\mathbf{M}+\mathbf{H}]^{+}\right)$. Structures predicted to each molecular ion $(381,355,335$, and $219 \mathrm{~m} / \mathrm{z}$ ), obtained from CFM-ID platform.

Figure 6. Mass spectra of callus extracts from both toxic and non-toxic varieties of $J$. curcas at 14 and $38 \mathrm{~d}$ culture, showing the relative intensity of the molecular ion $m / z, 381[\mathrm{M}+\mathrm{H}]^{+}$ related to the fragmentation profile from two glycosylated apigenin. A, and C) Extracts of $J$. curcas callus from $J$. curcas-toxic variety (14 and $38 \mathrm{~d}$, respectively). B, and D) Extracts of $J$. curcas callus from non-toxic variety (14 and $38 \mathrm{~d}$, respectively). The relative intensity from molecular ion $m / z 381[\mathrm{M}+\mathrm{H}]^{+}$diminished throughout culture time. 
554 Table 1. Tentative compounds identified by ESI-MS in hydroalcoholic extracts from seeds, leaves, 555 and callus of 14 and $38 \mathrm{~d}$ of culture from both toxic and non-toxic Jatropha curcas L.varieties.

556

557 Supplementary material description

558 Figure S1. Thin layer chromatogram of extracts obtained from seeds, leaves, and callus of 559 two $\mathbf{J}$. curcas-varieties with two extraction methods for the identification of phorbol esters 560 (Rf's 0.81, 0.53, and 0.38). The extracts obtained with ethanol 80\% - sonication are referred 561 with numbers $(1-8)$. The extracts obtained with Soxhlet - methanol are referred with letters (A 562 - H). PMA: Phorbol-12-myristate-13-acetate Rf 0.22 (Sigma, PE reference standard). Toxic 563 variety seed (1 and A), Non-toxic variety seed (2 and B), Toxic variety leaves (3 and C), Non564 toxic variety leaves (4 and D), Toxic variety-callus $14 \mathrm{~d}$ (5 and E), Toxic variety-callus $38 \mathrm{~d}$ (6 565 and F), Non-toxic variety-callus $14 \mathrm{~d}$ (7 and G), Non-toxic variety-callus $38 \mathrm{~d}$ ( 8 and H). Mobile 566 phase chloroform-methanol (97:3), cerium sulfate-revealed, observed at $366 \mathrm{~nm}$ UV light.

567 Figure S2. Predicted structures related with the fragmentation profile from six flavonoids 568 identified through ESI-MS from calluses extracts of non-toxic Jatropha curcas. It is included 569 the predictive structure corresponding to vicenin-2,6"-O-Glucoside $\mathrm{m} / \mathrm{z} 757[\mathrm{M}+\mathrm{H}]^{+}$which is not 570 reported to Jatropha curcas, but it is to Stellaria holostea. 


\section{Figure 1}

Figure 1

Cell dedifferentiation of petiole explants from both toxic and non-toxic varieties of Jatropha curcas.

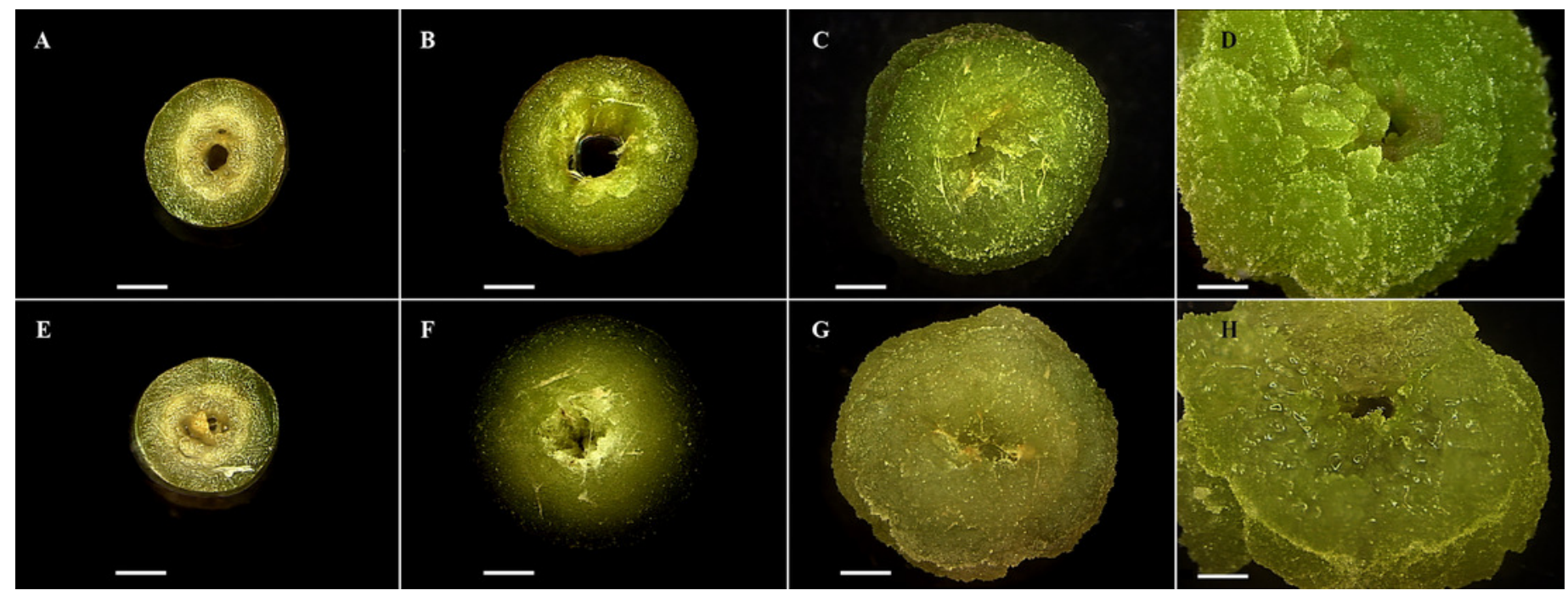




\section{Figure 2}

Figure 2

Identification of both diterpenes-type (A), and flavonoids-type (B) compounds in seeds, leaves, and callus of Jatropha curcas, through thin layer chromatography

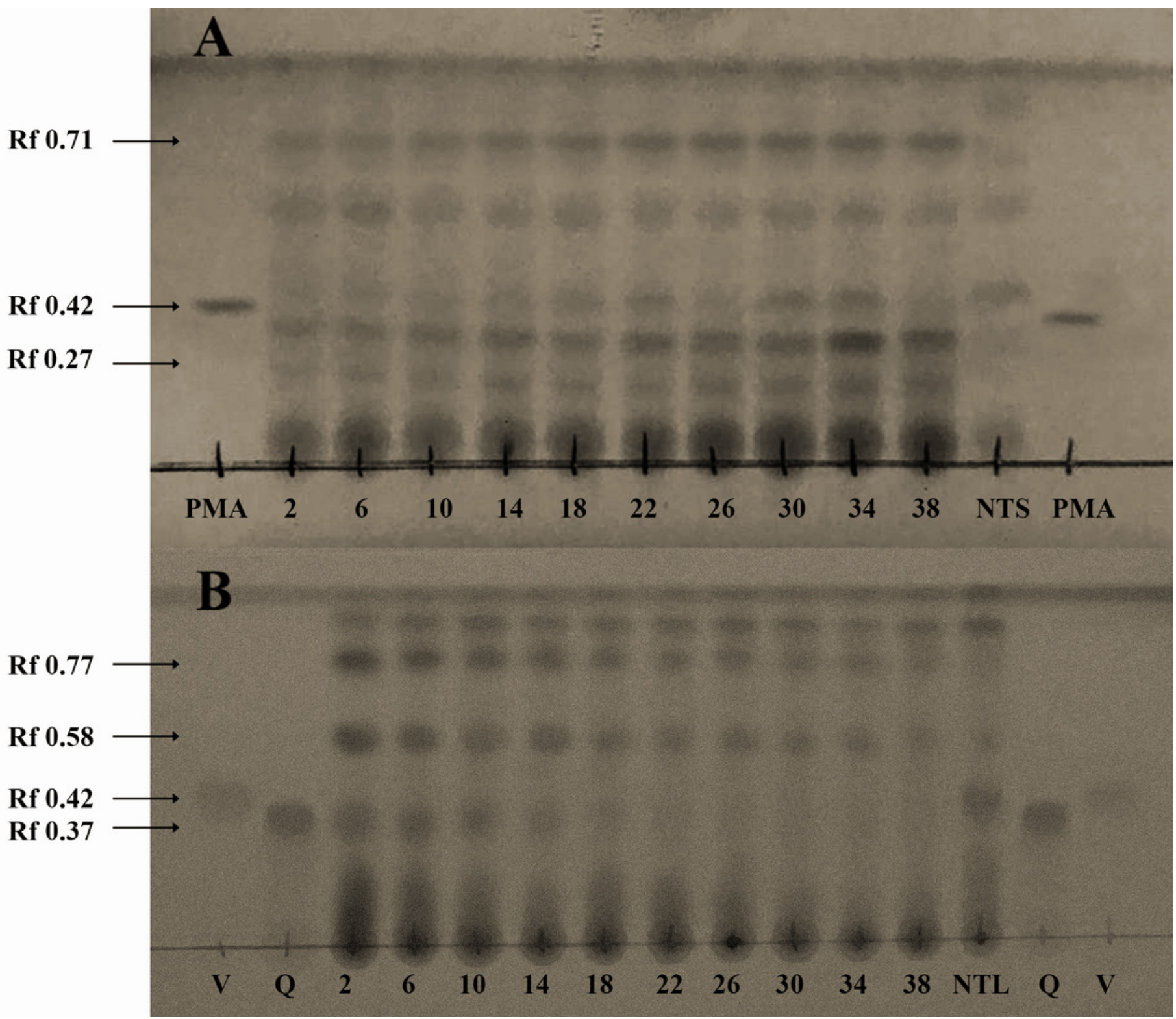


Figure 3

Figure 3

Spectrophotometrical analysis of phorbol esters in extracts of Jatropha curcas seeds

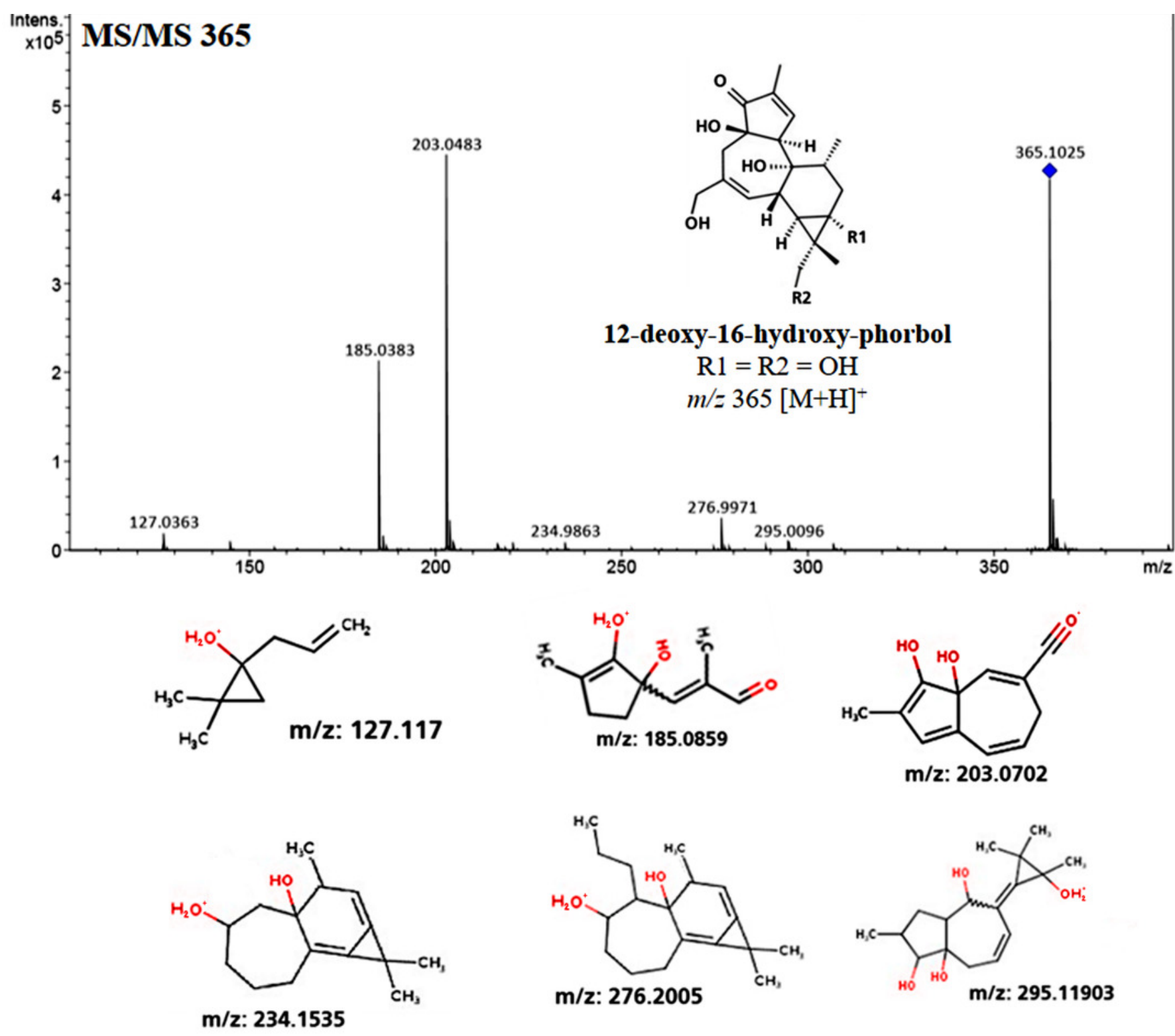




\section{Figure 4}

Figure 4

Mass spectra from callus extracts of $J$. curcas showing the relative intensity of the molecular ion $\mathrm{m} / \mathrm{z} 365[\mathrm{M}+\mathrm{H}]^{+}$related to the structural core of the Jatropha-phorbol esters

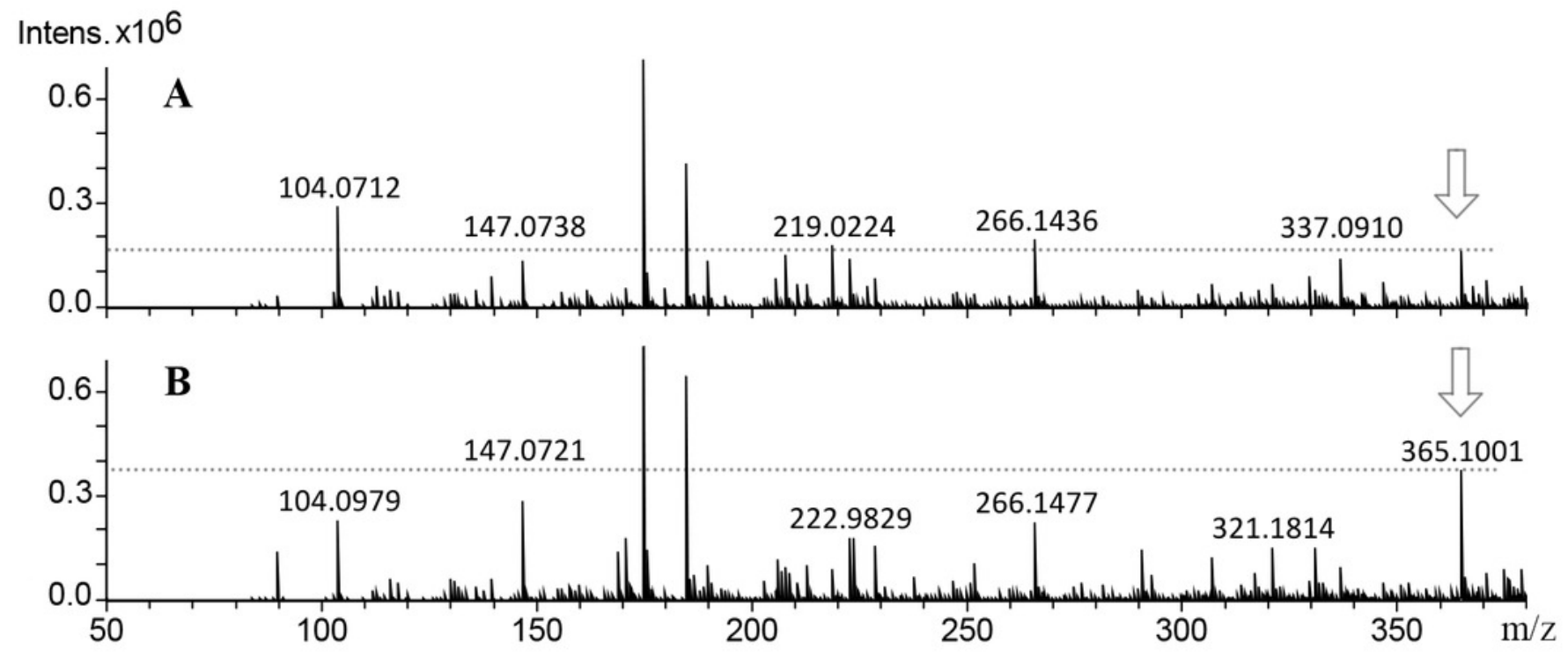

Intens. $\times 10^{6}$
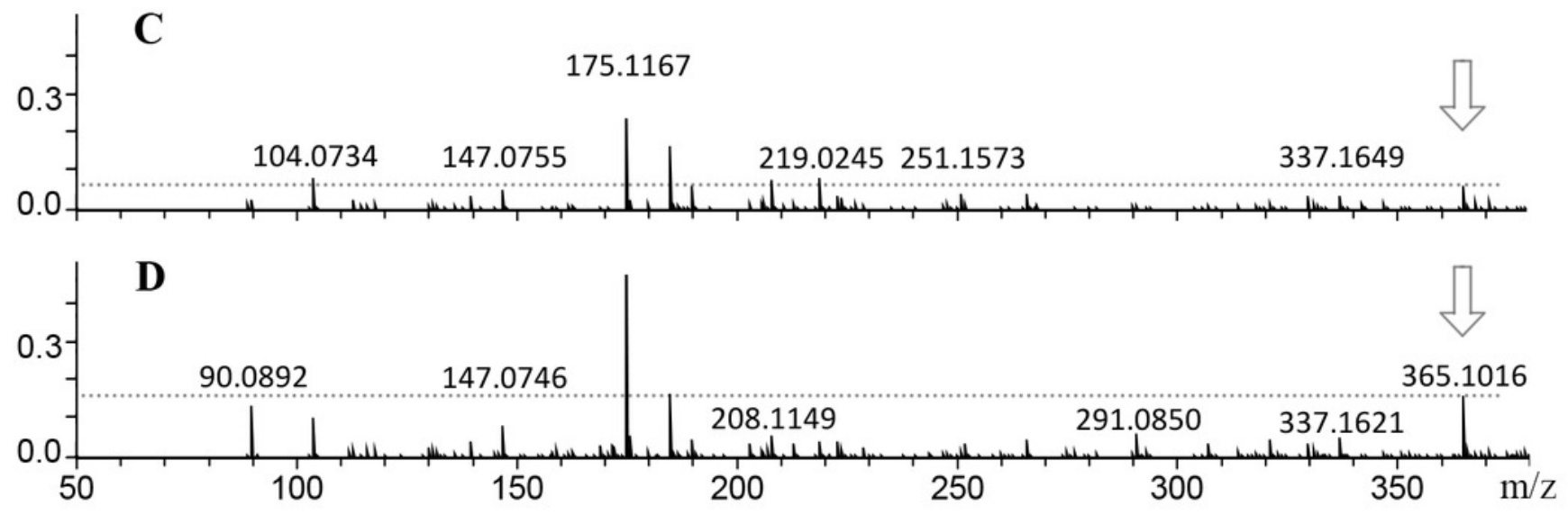
Figure 5

Figure 5

Fragmentation profile (MS/MS) of the molecular ion $\mathrm{m} / \mathrm{z} 381[\mathrm{M}+\mathrm{H}]^{+}$, observed in leaves extracts, and related to fragmentation of two glycosylated apigenin (apigenin (apigenin 6-C$\alpha$-L-arabinopyranosyl-8-C- $\beta$-D-xylopyranoside $m / z 535[\mathrm{M}+\mathrm{H}]^{+}$, apigenin 4'-O-rhamnoside $m / z$ $\left.417[\mathrm{M}+\mathrm{H}]^{+}\right)$

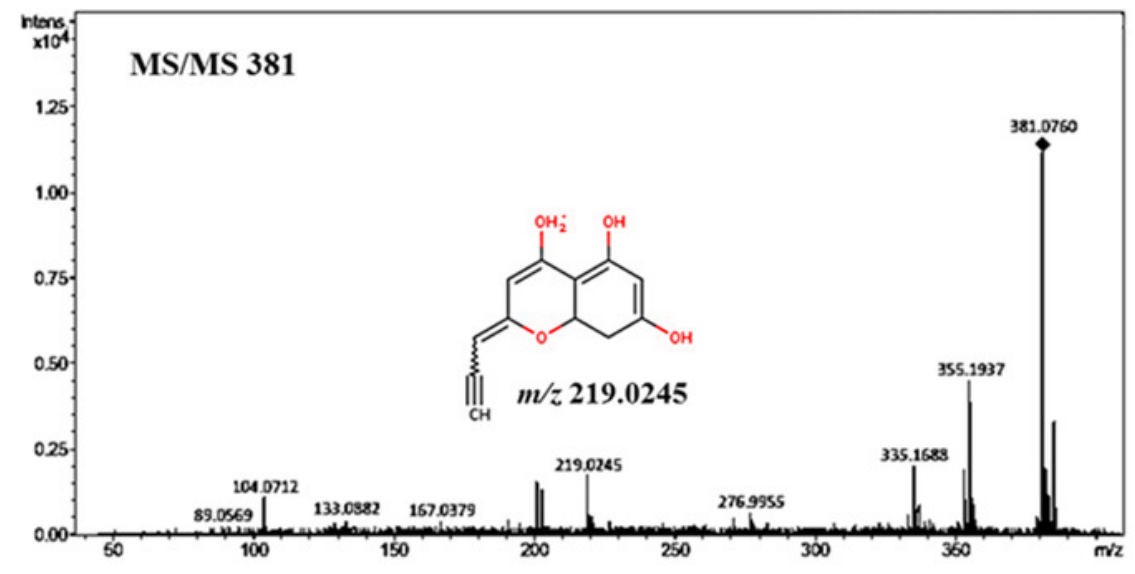

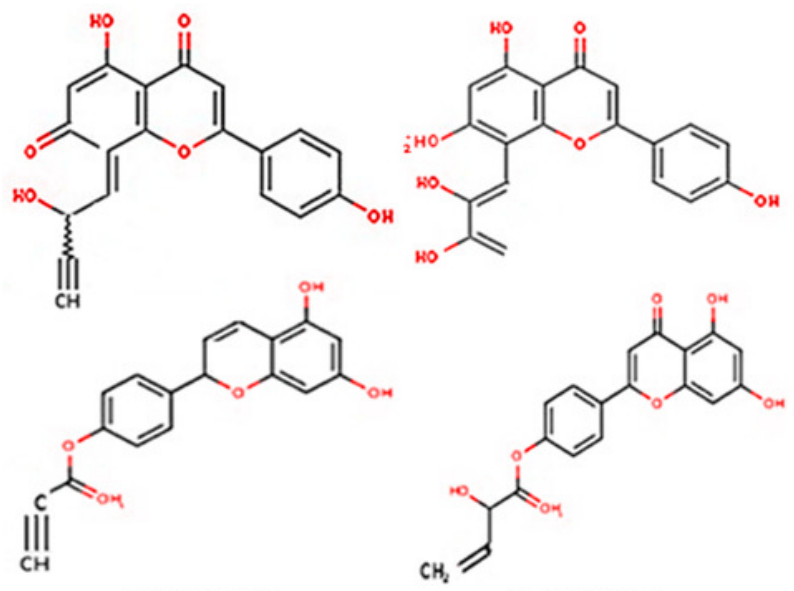

$m / z 335.1688$

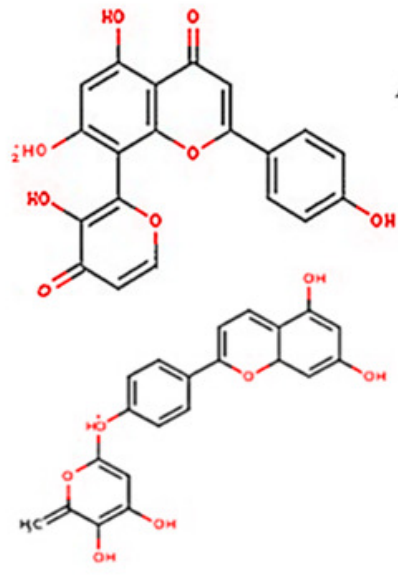

$m / z 381.0764$

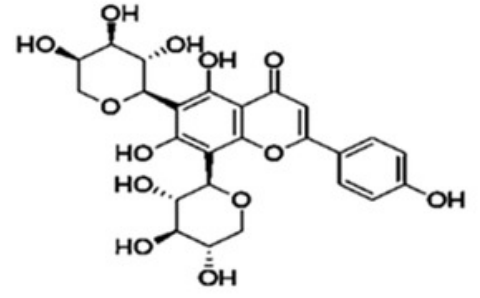

Apigenina 6-C- $\alpha$-L-arabinopiranosil-8-C- $\beta$-Dxilopiranósido $m / z$ : $\mathbf{5 3 5}[\mathrm{M}+\mathrm{H}]^{+}$<smiles>C[C@H]1O[C@H](Oc2ccc(-c3cc(=O)c4c(O)cc(O)cc4o3)cc2)[C@H](O)[C@@H](O)[C@@H]1O</smiles>

Apigenina 4'-O-ramnosido $m / z 417[\mathrm{M}+\mathrm{H}]^{+}$ 


\section{Figure 6}

Figure 6

Mass spectra of callus extracts from both toxic and non-toxic varieties of $J$. curcas at 14 and $38 \mathrm{~d}$ culture, showing the relative intensity of the molecular ion $\mathrm{m} / \mathrm{z} 381[\mathrm{M}+\mathrm{H}]^{+}$related to the fragmentation profile from two glycosylated apigenin 
Intens. $\times 10^{6}$
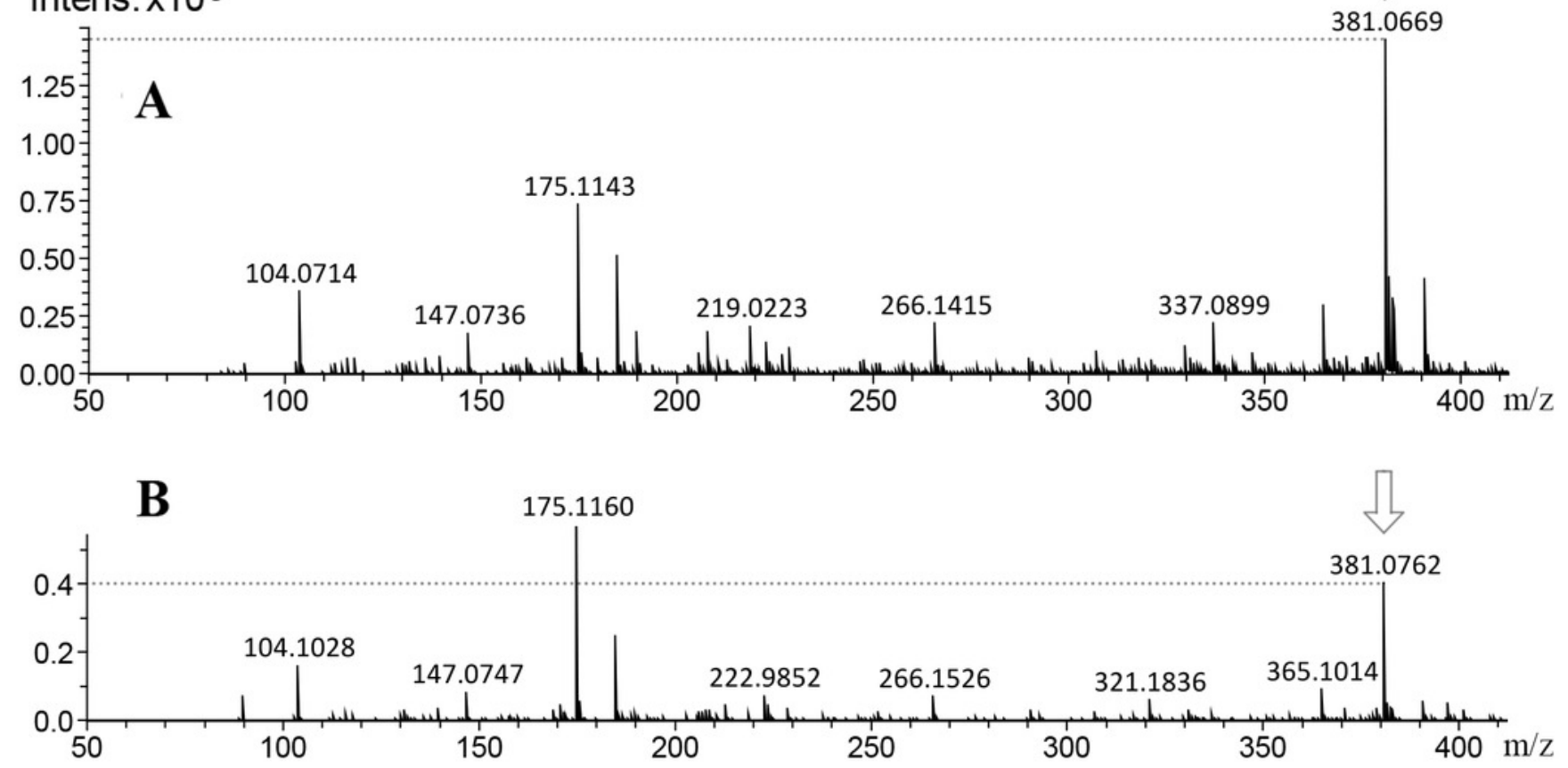

Intens. $\times 10^{6}$

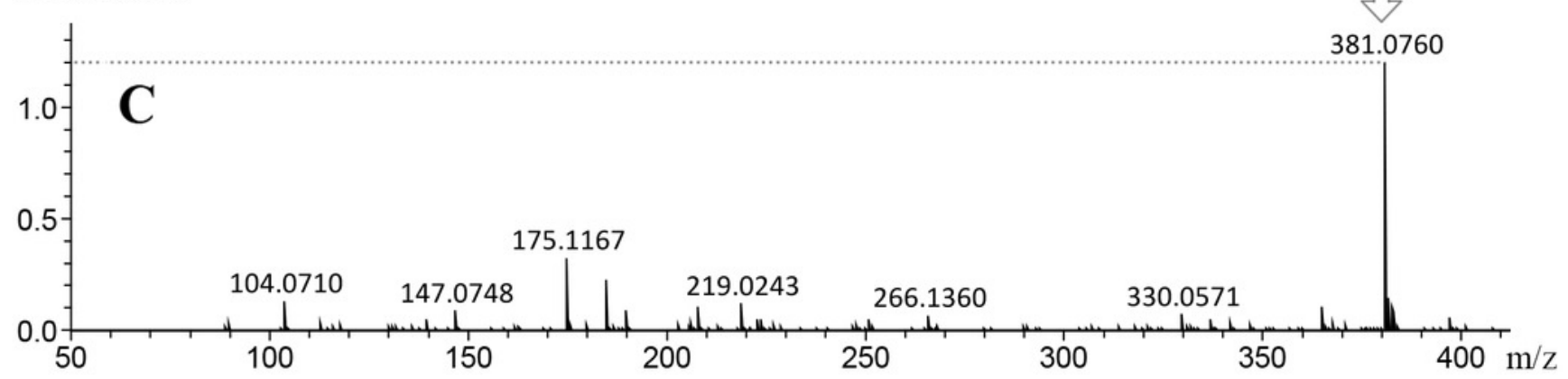

D

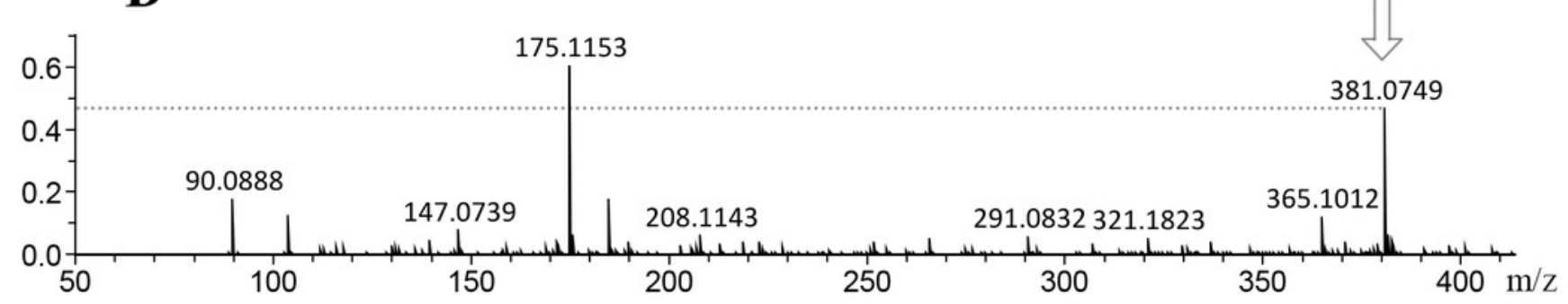




\section{Table $\mathbf{1}$ (on next page)}

Table 1

Tentative compounds identified by ESI-MS in hydroalcoholic extracts from seeds, leaves, and callus of 14 and $38 \mathrm{~d}$ of culture from both toxic and non-toxic Jatropha curcas L. varieties 
Table 1. Tentative compounds identified by ESI-MS in hydroalcoholic extracts from seeds, leaves, and callus of 14 and $38 \mathrm{~d}$ of culture from both toxic and non-toxic Jatropha curcas L. varieties.

\begin{tabular}{|c|c|c|c|c|c|c|c|}
\hline Compound type/name & $\begin{array}{c}\text { Elemental } \\
\text { Composition }\end{array}$ & Mass & $\begin{array}{l}\text { Fragment } \\
\text { Ions in } \\
\text { Positive Ion } \\
\text { Mode }(\mathrm{m} / \mathrm{z})\end{array}$ & $\begin{array}{c}\text { Plant } \\
\text { material }\end{array}$ & $\begin{array}{l}\text { Time of } \\
\text { culture } \\
\text { (d) }\end{array}$ & Variety & $\begin{array}{l}\text { Relative } \\
\text { abundance } \\
\quad(\%)\end{array}$ \\
\hline \multicolumn{8}{|l|}{ Phorbol } \\
\hline \multirow{6}{*}{$\begin{array}{l}\text { 12-deoxy-16-hydroxy- } \\
\text { phorbol }\end{array}$} & \multirow{6}{*}{$\mathrm{C}_{20} \mathrm{H}_{28} \mathrm{O}_{6}$} & \multirow{6}{*}{364.4} & \multirow{6}{*}{$\begin{array}{l}127,185, \\
203,234, \\
276,295\end{array}$} & \multirow{2}{*}{\multicolumn{2}{|c|}{ Seeds }} & $\mathrm{T}$ & 64.70 \\
\hline & & & & & & NT & 21.05 \\
\hline & & & & \multirow{4}{*}{ Callus } & \multirow[t]{2}{*}{14} & $\mathrm{~T}$ & 14.28 \\
\hline & & & & & & NT & 8.69 \\
\hline & & & & & \multirow[t]{2}{*}{38} & $\mathrm{~T}$ & 30.00 \\
\hline & & & & & & NT & 25.00 \\
\hline \multicolumn{8}{|l|}{ Glycosylated Flavonoids } \\
\hline \multirow{6}{*}{$\begin{array}{c}\text { Apigenin 6-C- } \alpha \text {-L- } \\
\text { arabinopyranosyl-8-C- } \beta \text {-D- } \\
\text { xylopyranoside }(m / z \text { 535 } \\
\left.[\mathrm{M}+\mathrm{H}]^{+}\right) \text {and Apigenin } 4^{\prime}- \\
O \text {-rhamnoside }(m / z, 417 \\
\left.[\mathrm{M}+\mathrm{H}]^{+}\right)\end{array}$} & \multirow{6}{*}{$\begin{array}{c}\mathrm{C}_{25} \mathrm{H}_{26} \mathrm{O}_{13} \\
\text { and } \mathrm{C}_{21} \mathrm{H}_{20} \mathrm{O}_{9}\end{array}$} & \multirow{6}{*}{$\begin{array}{c}534.47 \\
\text { and } \\
416.4\end{array}$} & \multirow{6}{*}{381} & \multirow{2}{*}{\multicolumn{2}{|c|}{ Leaves }} & $\mathrm{T}$ & 45.83 \\
\hline & & & & & & NT & 100 \\
\hline & & & & \multirow{4}{*}{ Callus } & \multirow{2}{*}{14} & $\mathrm{~T}$ & 100 \\
\hline & & & & & & NT & 100 \\
\hline & & & & & \multirow{2}{*}{38} & $\mathrm{~T}$ & 100 \\
\hline & & & & & & NT & 62.50 \\
\hline \multirow{6}{*}{ Vitexin $\left(m / z 433[\mathrm{M}+\mathrm{H}]^{+}\right)$} & \multirow{6}{*}{$\mathrm{C}_{21} \mathrm{H}_{20} \mathrm{O}_{10}$} & \multirow{6}{*}{432.37} & \multirow{6}{*}{415} & \multirow{2}{*}{\multicolumn{2}{|c|}{ Leaves }} & $\mathrm{T}$ & 27.27 \\
\hline & & & & & & NT & 70.00 \\
\hline & & & & \multirow{4}{*}{ Callus } & \multirow{2}{*}{14} & $\mathrm{~T}$ & 10.34 \\
\hline & & & & & & NT & 4.76 \\
\hline & & & & & \multirow{2}{*}{38} & $\mathrm{~T}$ & 11.11 \\
\hline & & & & & & NT & $<12.50$ \\
\hline & & & & & & $\mathrm{T}$ & 33.33 \\
\hline Vitexin 4'-O-glucoside-2"- & & & & Leaves & & NT & 42.84 \\
\hline O-rhamnoside $(\mathrm{m} / z 741$ & $\mathrm{C}_{33} \mathrm{H}_{40} \mathrm{O}_{19}$ & 740.7 & 577 & & 14 & $\mathrm{~T}$ & 1.42 \\
\hline & & & & Callus & 14 & NT & 6.36 \\
\hline & & & & & 38 & $\mathrm{~T}$ & 12.50 \\
\hline & & & & & 58 & NT & 8.75 \\
\hline & & & & & & $\mathrm{T}$ & 25.00 \\
\hline & & & & Leaves & & NT & 29.16 \\
\hline Vicenin-2 $(\mathrm{m} / \mathrm{z} 595$ & $\mathrm{C}_{27} \mathrm{H}_{30} \mathrm{O}_{15}$ & 594.5 & 503 & & 14 & $\mathrm{~T}$ & 7.14 \\
\hline$\left.[\mathrm{M}+\mathrm{H}]^{+}\right)$ & & & & Callus & 14 & NT & 4.00 \\
\hline & & & & & 38 & $\mathrm{~T}$ & 6.25 \\
\hline & & & & & 58 & NT & 3.75 \\
\hline & & & & I eaves & & $\mathrm{T}$ & $<9.09$ \\
\hline & & & & Leaves & & NT & 8.00 \\
\hline Vicenin-2,6"-O-glucoside & $\mathrm{C}_{33} \mathrm{H}_{40} \mathrm{O}_{20}$ & 756.7 & 757 & & & $\mathrm{~T}$ & 1.42 \\
\hline$\left(m / z 757[\mathrm{M}+\mathrm{H}]^{+}\right)$ & & & & Callus & 14 & NT & $\mathbf{1 . 7 3}$ \\
\hline & & & & & 38 & $\mathrm{~T}$ & 2.22 \\
\hline & & & & & 38 & NT & 1.25 \\
\hline
\end{tabular}

$* \mathrm{~T}=$ Toxic, $\mathrm{NT}=$ Non-toxic 